\title{
Al-Madãris
}

VOL. 2, NO. 1, 2021

E-ISSN: 2745-9950

https://journal.staijamitar.ac.id/index.php/almadaris

\section{HUKUM, HAKIM, MAHKUM FIH DAN MAHKUM 'ALAIH(STUDI PEMAHAMAN DASAR ILMU HUKUM ISLAM)}

\author{
Isnu Cut Ali \\ Prodi Hukum Ekonomi Syariah (Muamalah) STAI Jamiatut Tarbiyah Lhoksukon \\ icacut.2018@gmail.com
}

\begin{abstract}
In the terms of the ushul scholars, law is defined as a khitabsyari 'which is related to the actions of mukallaf, whether they are thalab (demands), takhyiir (choice) or wadl'i (provisions). Meanwhile, law according to fiqh experts is a syar'i characteristic which is the influence of the khitab. Thus, the influence of Allah's khitab which implies the obligation to perform prayers from the verse "Aqiimu as-Sholaah" is a law. Essentially the judge is Allah Almighty. Simply, nothing else. The messengers of Allah only convey the message and the laws. They all did not create or enforce laws. Meanwhile the mujtahids were merely exposing the veils of the law. They are also not creators of Sharia law, even though by custom they are also sometimes called judges. What is meant by mahkumfih is the act of a mukallaf related to taklif / imposition. Taklif which comes from Allah is aimed at man in every one of his actions. Mahkumalaih is a mukallaf whose actions are related to the law of shari '.
\end{abstract}

Keywords: Islamic law, ushul fiqh.

$\overline{\text { Al-Madaris, Volume 2 (1), } 2021}$ 


\section{A. Pendahuluan}

Sebagai sebuah agama, Islam mempunyai berbagai macam aturan, hokum sekaligus dogma-dogma teologis. Hukum-hukumtersebutditetapkantuhan demi terciptasuatukehidupan yang berorientasi pada kebahagiaanumat, baik di dunia maupunakhirat.

Karakteristik hukum Islam yang bersendikan nash dan didukung dengan akal merupakan ciri khas yang membedakannya dengan sistem hukum lainnya. Ijtihad memegang peranan signifikan dalam pembaruan dan pengembangan hukum Islam. Hal ini merupakan pantulan dari sebuah adagium dari seorang Syahrastani yang kemudian berkembang menjadi statement populer di kalangan para pakar hukum Islam yaitu "teks-teks nash itu terbatas, sementara problematika hukum yang memerlukan solusi tidak terbatas".

Mediator utama dalam memecahkan problem-problem keagamaan adalah dengan berijtihad. Sebagai sebuah mediator, ia juga memerlukan perangkatperangkat supaya mampu menghasilkan solusi-solusi cerdas dan tepat bagi problem-problem tersebut.

Salah satu perangkat untuk melakukan aktifitas ijtihad adalah dengan memahami metodologi ushul fiqih, sebab denganya seseorang akan mampu menyelami dan memahami dalil-dalil syar'i yang pada akhirnya akan menemukan hukum-hukum Islam dari pesan-pesan tuhan secara langsung maupun tidak langsung.

Di antara sekian banyak wilayah cakupan fan ushul fiqh yang amat penting untuk diketahui adalah konsep tentang hukum, hakim, mahkum fih dan mahkum alaih. Sebab sebelum seseorang terjun untuk menjawab persoalan sebuah hukum, ia diharuskan untuk mengetahui terlebih dahulu apa itu hukum, kemudian siapa pembuatnya dan siapa obyeknya.

Berpijak dari hal di atas, maka dalam tulisan ini akan dieksplorasi secara komprehensif tentang istilah-istilah tersebut yang meliputi hakim, hukum, mahkum fih dan mahkum alaih.

\section{B. Review Literatur}

Di dalam kitab Al Wadhih Fi Ushul Al Fiqh bagian ke -2, dinukil oleh seorang ulama kontemporer Muhammad Husain Abdullah, dan diterjemahi oleh pengkaji tema kajian ini, beliau menukilkan beberapa pokok bahasan dan pengertian yang menyangkut tentang hukum syara' sebagai berikut:

\section{Hukum}

Allah Swt telah menyerukan syari'at Islam seluruhnya kepada manusia, baik yang menyangkut 'aqidah maupun hukum-hukum syara' yang berkenaan dengan perbuatan.Tetapi ilmu ushul al fiqh tidak membahas permasalahan 'aqidah, melainkan hanya membahas tentang hukum-hukum syara' yang berkenaan dengan perbuatan, yaitu mengenai aspek dasar yang akan menjadi landasan. Tentu ulama ushul al figh telah mendefinikan hukum syara', dan telah menjelaskan pembagiannya. 
a. Definisi Hukum :

Hukum menurut bahasa: al man'u (pencegahan), seperti dikatakan orang: حكم الحصان, artinya: mencegah kuda berlari. Diantaranya perkataan Jarir sebagai seorang penyair :

$$
\text { أبني حنيفة أحكموا سفهاءكم إني أخاف عليكموا أن أغضبا أي امنعوا سفهاءكم }
$$

"Apakah Bani Hanifah yang telah menghukumi - mencegah - semua anak kalian yang tidak cukup akal itu, sesungguhnya aku takut bersikap marah terhadap kalian".

b. Hukum menurut istilah :

$$
\text { الحكم هو خطاب الشارع المتعلق بأفعال العباد بالإقتضاء أو التخيير أو الوضع }
$$

"Seruan Al Syari' yang berhubungan dengan segala perbuatan para hamba, menyangkut tuntutan, atau pilihan, atau kondisi".

c. Penjelasan definisi :

1) خطاب الثارع : yaitu semua makna yang terkandung dalam lafazh-lafazh maupun susunan-susunan didalam nash-nash syara', seperti ayat-ayat al qur-an dan hadits-hadits. Terkadang seorang mujtahid telah melakukan istimbath hukum dari sebuah ayat yang berbeda dengan hukum yang diistimbath oleh mujtahid yang lain, sehingga hukum syara' berlaku pada diri masing-masing mujtahid sesuai dengan apa yang telah diistimbathnya dari pemahaman nash. Disebutkan dengan sebutan "Al Syari", bukan "Allah", karena seruan itu mencakup seruan sunnah, ijma' shahabat dan qiyas, sebab semuanya menunjukkan seruan Allah swt, sehingga maksud seruan itu tidak hanya tergambar pada al qur-an saja, lantaran keberadaannya sebagai kalam Allah swt secara lafazh dan maknanya. Disebutkan pula dengan seruan Al Syari', karena menunjukkan apa saja yang diarahkan oleh kalam yang ada dalam setiap nash, maksudnya menunjukkan makna lafazh, karena kalam itu sendiri terkadang dapat dipahami lebih dari satu makna, maka makna yang dipahami oleh seorang mujtahid itu adalah hukum Allah swt atas dirinya sendiri dan hukum Allah swt atas diri orang yang mengikutinya.

2) yaitu suatu persoalan yang tidak membahas masalah 'aqidah, melainkan hanya membahas masalah hukum-hukum syara' yang berhubungan dengan perbuatan para hamba. Adapun pembahasan mengenai 'aqidah telah dibahas dalam ilmu kalam atau dalam ilmu tauhid. Disebutkan dengan sebutan "Al 'Tbad", bukan "Al Mukallafin" sebagaimana yang telah ada pada beberapa definisi, karena mencakup segala hukum yang berkenaan dengan anak kecil dan orang gila sehubungan dengan masalah zakat dan harta benda.

3) الإقتضاء : yaitu tuntutan. Tuntutan ini terbagi menjadi dua bagian, yaitu tuntutan melakukan dan tuntutan meninggalkan.

a) Tuntutan melakukan: Jika berbentuk jazim (tegas), maka tuntutan tersebut hukumnya fardhu atau wajib. Jika berbentuk ghairu jazim 
(tidak tegas), maka tuntutan tersebut hukumnya mandub atau sunnah atau nafilah.

b) Tuntutan meninggalkan: Jika berbentuk jazim (tegas), maka tuntutan tersebut hukumnya haram atau mahzhur. Jika berbentuk ghairu jazim (tidak tegas), maka tuntutan tersebut hukumnya makruh.

4) yaitu boleh memilih antara melakukan dan meninggalkan.

5) yaitu menjadikan sesuatu sebagai sabab, atau syarat, atau mani' terhadap hukum syara', ataupun yang semisalnya, seperti shihhah, fasad, buthlan, 'azimah dan rukhshah.

Dengan demikian, maka sebagian definisi hukum syara' "seruan syari' yang berhubungan dengan segala perbuatan para hamba, menyangkut tuntutan dan pilihan" meliputi lima macam hukum, yaitu: wajib, mandub, haram, makruh dan mubah. Kelima macam hukum ini disebut "Hukum Taklifi", sedangkan sebagian sisanya "seruan syari' yang berhubungan dengan segala perbuatan para hamba, menyangkut kondisi" meliputi apa-apa yang menjadi sabab, syarat, mani', shihhah - buthlan - fasad, rukhshah - 'azimah. Semua ini disebut dengan Hukum Wadh'i.

\section{Pembagian Hukum Syara'}

Hukum syara' terbagi menjadi dua bagian: 1) Hukum Syara' Taklifi dan 2) Hukum Syara' Wadh'i

a. Hukum Syara' Taklifi: Yaitu seruan Al Syari' yang berhubungan dengan segala perbuatan para hamba, menyangkut tuntutan dan pilihan. Hukum tersebut dinamakan dengan taklifi, karena mengandung taklif (pembebanan) kepada manusia dalam bentuk tuntutan melaksanakan atau tuntutan meninggalkan, ataupun memilih antara melaksanakan dan meninggalkan. Hukum Syara' Taklifi terbagai menjadi lima macam:

1) Wajib : yaitu apa yang dituntut pelaksaannya oleh Al Syari' (pembuat hukum) secara tegas, misalnya zakat.

2) Mandub : yaitu apa yang dituntut pelaksnaannya oleh Al Syari' (pembuat hukum) secara tidak tegas, misalnya shadaqah.

3) Haram : yaitu apa yang dituntut meninggalkannya oleh Al Syari' (pembuat hukum) secara tegas, misalnya zina dan riba.

4) Makruh : yaitu apa yang dituntut meninggalkannya oleh Al Syari' (pembuat hukum) secara tidak tegas, misalnya berlama-lama di kamar mandi.

5) Mubah : yaitu hak pilih yang diberikan oleh Al Syari' (pembuat hukum) kepada seorang mukallaf, antara melaksanakan dan meninggalkan, misalnya minum air dan bepergian.

b. Hukum Syara' Wadh'I; Hukum Syara' Wadh'i adalah seruan Al Syari' yang berhubungan dengan segala tingkah laku para hamba berkaitan dengan keadaan. Hukum-hukum Wadh'i adalah segala perkara yang buat (dikondisikan) untuk hukum-hukum taklifi, seperti sabab, syarat, mani' dan lain-lainnya demi merealisasikan hukum-hukum tersebut dan menyempurnakannya. Dengan demikian, maka seruan taklifi 
berhubungan dengan perbuatan manusia secara langsung. Adapun seruan wadh'i, seruannya berhubungan dengan seruan taklifi, maka seruan wadh'i tersebut menjadi seruan yang berhubungan dengan perbuatan manusia secara tidak langsung. Contoh hukum wadh'i:

"Zakat merupakan hukum taklifi, yaitu wajib. Masa setahun yang berlaku pada nisab zakat merupakan syarat dalam kewajiban berzakat, namun jika belum terpenuhi syarat ini dalam nisab zakat, maka gugurlah kewajiban berzakat. Dengan demikian, syarat tersebut merupakan bagian dari hukum-hukum wadh'i" (Wahbah az-Zuhaili, t.t.: 108).

Maka hukum-hukum wadh'i itu diperuntukkan bagi hukum-hukum taklifi, yang memberikannya sifat-sifat tertentu. Hukum-hukum wadh'i tersebut dibutuhkan untuk merealisasikan hukum-hukum taklifi dan untuk mencapai kesempurnaannya, sebagaimana dalam pemisalan zakat tadi.

c. Macam-macam hukum syara' wadh'i. Ada lima macam hukum syara' wadh'i : 1) Sabab, 2) Syarat, 3) Mani' 4) Shihhah - buthlan - fasad dan 5) Rukhshah-'azimah.

Sebagian ulama fikih hanya menjadikan tiga macam saja: sabab, syarat dan mani'. Ada sebagian ulama fikih lainnya menjadikan empat macam saja, yaitu dengan menambahkan : shihhah - buthlan - fasad setelah tiga macam di atas. Namun ada pula sebagian yang lain menjadikan lima macam, yaitu dengan menambahkan rukhshah 'azimah setelah empat macam diatas.

Karena terjadi perbedaan pendapat dikalangan ulama fikih tentang dua macam yang terakhir, yaitu shihhah - buthlan - fasad dan rukhshah - 'azimah, maka sebagian mereka menganggapnya termasuk dalam hukum taklifi, namun sebagian yang lain menganggapnya termasuk dalam hukum wadh'i. Tetapi yang lebih mendekati kebenaran adalah semuanya termasuk dalam hukum wadh'i, karena yang demikian itu merupakan sifat bagi hukum taklifi, bukan sebagai macam (jenis) dari lima macam hukum taklifi, yaitu : wajib, mandub, haram, makruh dan mubah. Ketika kita mengatakan bahwa akad ini shahih atau batal atau fasid, merupakan suatu sifat untuk hukum taklifi, bukan sebagai hukum taklifi, karena hukum taklifi tentang akad tersebut, kemungkinan wajib, atau haram, atau mandub atau lain-lain sebagainya.

\section{Metodelogi}

Salah satu fungsi pendekatan dalam penelitian adalah mempermudah analisis, memperjelas pemahaman terhadap obyek, memberikan nilai obyektifitas sekaligus membatasi wilayah penelitian, (Andi Prastowo, 2011:181). Penulisan kajian ini menggunakan metode pendekatan hukum terhadap tema penulisan yang dikaji. Sedangkan jenis pengkajiannya adalah pengkajian berdasarkan metode kualitatif, agar dapat memandang sesuatu secara utuh (holistik), kompleks, dinamis, penuh makna, (Sugiono,2011:8) 
Dari segi tempat, bentuk pengkajian ini merupakan kajian literer (Library Research), karena pengkaji mempelajari suatu masalah, kemudian dicari data yang terkait dari berbagai literatur, baik berupa buku ataupun bahan dokumentasi, majalah ensiklopedi dan lain sebagainya yang bersifat tertulis, terutama bukubuku yang terkait dengan ilmu ushul fiqh serta literatur-literatur yang berkaitan dengan masalah, (Hadari Nawawi, 1990:9).

\section{Hasil Kajian}

Terkait dengan persoalan Hakim dalam makna hakiki, maka pengkaji perlu memperjelas kedudukannya menurut pandangan para kelompok mazhab yang ada dalam riang lingkup umat Islam ini. Menurut Abdul Wahab Khallaf, beliau membagi menjadi tiga kelompok, yaitu :

a. Mazhab Asy'ariyah, pengikut Abu Hasan al-Asy'ari yang menyatakan bahwa akal dengan sendirinya tidak akan mampu mengetahui hukum-hukum allah tanpa mediasi para rasul dan kitab-kitabnya. Kelompok ini berargumen bahwa yang disebut dengan kebaikan adalah sesuatu yang telah ditunjukkan oleh syari' bahwa hal itu memang baik. Sementara kejelekan adalah sesuatu yang ditunjukkan oleh syari' bahwa hal itu memang jelek. Kebaikan dan keburukan tidak dapat ditentukan oleh penalaran akal semata.

b. Mazhab Mu'tazilah, yakni para pengikut Washil bin Atha' yang menyatakan bahwa dengan sendirinya akal mampu mengetahui hukum-hukum Allah tanpa melalui perantara rasul atau kitab. Mereka berhujjah bahwa sesuatu itu dikatakan baik ketika akal memandang hal itu baik. Sebaliknya sesuatu itu dipandang jelek ketika akal memang menganggap jelek.

c. Mazhab Maturidiyah, pengikut Abu Mansur al-Maturidi, mazhab ini menurut Khallaf adalah mazhab penengah dan dianggap sebagai pendapat yang lebih kuat. Mazhab ini menyatakan bahwa memang akal sehat itu mampu menilai mana yang baik dan mana yang dianggap buruk. Namun, tidak secara otomatis akal mampu menentukan hukum-hukum Allah, sebab kerja akal itu terbatas dan terkadang kerja akal itu berbeda satu sama lain dalam menilai suatu perbuatan. Oleh karena itulah, dalam menentukan hukum-hukum Allah tetap diperlukan adanya perantara utusan dan kitab-kitabnya, (Wahab Khallaf,: 97-99).Pada akhirnya apa yang dipegangi oleh mazhab ini sama dengan pendapat mazhab Asy'ariyah yang tetap menyatakan bahwa untuk mengetahui hukum Allah diperlukan adanya perantara.

Terkait perbedaan para ulama di atas, pendapat yang dipegangi oleh kelompok kedualah yang sebenarnya terasa lebih relevan. Sebab, dalam pendapat kedua ini tersimpan keadilan Tuhan yang begitu luar biasa. Betapa tidak, menurut pendapat ini seorang yang belum sampai dakwah Islam kepadanya, akan tetap dituntut sebagai seorang mukallaf berdasar akal yang dianugerahkan padanya. Hal ini logis, sebab salah satu syarat utama seorang mukallaf haruslah ia memiliki akal sehat. Ia dituntut untuk melaksanakan perbuatan yang dianggap baik oleh akal sehatnya dan dituntut meninggalkan perbuatan yang dianggap 
buruk menurut akal sehatnya pula. Ini merupakan apresiasi yang luar biasa besar terhadap anugerah akal yang diberikan oleh Tuhan.

\section{E. Pembahasan \\ 1. Hukum}

Secara bahasa hukum berarti putusan. Ketika diucapkan "Hakama Allahu fi al-Mas'alah al-wujuub", maka ia mempunyai arti Allah memutuskan masalah ini dengan putusan wajib, (Abdul Karim Ali, 1999: 125). Dalam istilah ulama ushul, hukum didefinisikan sebagai suatu khitab syari' yang berkaitan dengan perbuatan-perbuatan mukallaf, baik yang bersifat thalab (tuntutan), takhyiir (pilihan) atau wadl'i (ketetapan), (A. Wahab Khallaf, 1978: 100).

Untuk mempermudah pemahaman atas konsep hukum ini, perlu kiranya untuk sedikit mencermati salah satu firman Allah yang berbunyi "Aufuu bi al'Uquud". Ayat ini merupakan khitab Allah yang berkaitan dengan tuntutan pemenuhan janji. Pada nash yang lain dijumpai hadits Rasul yang berbunyi " $\mathrm{La}$ yaritsu al-Qaatilu". Ini juga merupakan salah satu khitab dari syari' yang berkaitan dengan sebuah ketetapan bahwasanya seorang pembunuh tidak diperkenankan mendapat warisan.Dengan demikian nash, yang muncul dari syari' yang berupa tuntutan, pilihan maupun ketetapan dalam istilah ulama ushul disebut sebagai sebuah hukum, (A. Wahab Khallaf,: 100).

Sedangkan hukum menurut pakar fiqih adalah suatu sifat syar'i yang merupakan pengaruh dari khitab tersebut. Dengan demikian, pengaruh khitab Allah yang berimplikasi pada kewajiban mendirikan shalat dari ayat "Aqiimu asSholaah" adalah sebuah hukum, (Wahbahaz-Zuhaili, t.t.: 4l).

Dari kedua definisi yang ditawarkan oleh masing-masing ulama ushul dan fiqih di atas, tampaknya yang acapkali muncul dan populer di masyarakat adalah definisi dari ulama fiqih. Ketika disebut kata "hukum", maka asumsi yang pertama kali muncul di memori otak seseorang adalah sebuah pengaruh atau sifat dari khitab syari'. Seseorang secara spontan akan mengatakan bahwa khitab Allah yang berbunyi "Aqiimu as-Sholaah" adalah ayat atau dalil dari al-Qur'an, padahal menurut ulama ushul nash tersebut adalah suatu hukum.

Dari sini, terlihat bahwa definisi dari ulama fiqih di samping lebih populer juga terasa lebih sederhana dan kuat. Sebab, sebagaimana dikatakan oleh azZuhaili dalam karyanya "Ushul al-Fiqh al-Islaami" bahwa definisi dari ulama ushul berimplikasi pada dua sisi pandang. Sisi pandang yang pertama adalah khitab syari' disebut sebagai sebuah hukum, dan sisi pandang yang kedua khitab itu disebut sebagai dalil. Berbeda dengan definisi dari ulama fiqih yang membedakan antara hukum dan dalil, (Az-Zuhaili,: 42-43). Maka, menurut hemat penulis, definisi dari ulamafiqih lah yang lebih layak untuk dipegangi.

\section{Klasifikasi Hukum}

Berdasarkan definisi dari ulama ushul, maka dapat diambil sebuah hipotesa bahwa hukum itu tidak hanya satu jenis saja, melainkan terdapat berbagai macam bentuk sesuai dengan kondisi khitab itu sendiri. Hampir seluruh ulama sepakat bahwa secara garis besar hukum terbagi menjadi dua bagian, yaitu hukum taklifi dan hukum wadl'iy. Namun, meski demikian tetap saja ada sebagian ulama yang menyatakan bahwa hukum itu tidak terbagi bagi, ia hanya 
satu yakni hukum taklifi saja. Di antara sebagian ulama yang menyatakan demikian adalah al-Baidlawi, (Abdul Karim,: 132).

Argumentasi logis al-Baidlowi dan sebagian ulama lainnya adalah bahwa adanya penetapan syarat bagi suatu hukum itu tak lain adalah sebuah bentuk pewajiban, sementara penetapan mani' (penghalang) bagi sesuatu merupakan bentuk larangan dan penetapan absahnya sesuatu tak lain adalah bentuk pembolehan untuk mengerjakan suatu pekerjaan (Abdul Karim,: 131-132). Maka, menurut kelompok ini, sebenarnya apa yang dilakukan oleh mayoritas ulama dalam mengklasifikasikan hukum ke dalam dua bagian sia sia belaka, sebab kandungan hukum wadl'iy sudah tercakup dalam hukum taklifi.Hukum taklifi adalah suatu hukum yang arahan khitabnya berorientasi pada tuntutan, larangan dan pilihan untuk sebuah pekerjaan, (Az-Zuhaili,: 121).

Contoh khitab syari' yang berupa tuntutan adalah firman Allah yang berbunyi "Khudz min Amwaalihim Shdaqatan", "wa lillahi 'ala an-Naas hijj al-Bait" dll. Dua khitab tersebut dimaksudkan menuntut seorang mukallaf untuk melakukan perbuatan. Selanjutnya adalah khitab syari' yang berupa larangan, seperti pada ayat "La taqrabu az-Zinaa" dll. Sementara khitab yang berorientasi pada pilihan (takhyiir) antara melakukan dan meninggalkan sebuah pekerjaan adalah seperti yang terdapat pada firman Allah "Fa idza Qudliyati ash-Solaat Fantasyiruu fil ardl", (Wahab Khallaf, 1978: 101). Sedangkan yang dimaksud dengan hukum wadl'iy adalah hukum yang berorientasi pada penetapan sesuatu untuk dijadikan sebagai sebab, syarat ataupun penghalang bagi sesuatu yang lain, (M. Rifa'I, t.t.: 14).

Contoh hukum wadli'y yang berupa sebab adalah seperti yang terkandung dalam firman Allah "Ya ayyuha al-Ladiina Amanuu Idza Qumtum ila as-Sholati faghsiluu Wujuuhakum....". Pada ayat ini dapat dipahami bahwa kehendak (iradah) untuk melaksanakan sholat merupakan sebab diwajibkannya melakukan ritual wudhu.Sedangkan contoh dari hukum wadl'iy yang berupa syarat adalah yang terkandung dalam firman Allah yang berbunyi "wa lillahi 'ala an-Naas Hijj al-Bait man istatha'a ilayhi Sabiila". Dari sini diketahui bahwa sifat "mampu" bagi seseorang menjadi syarat atas kewajiban haji, (Wahab Khallaf,: 102).

Contoh selanjutnya yang berkaitan dengan mani' (penghalang) adalah seperti yang terdapat dalam sabda Rasul yang berbunyi "laysa li al-Qaatil Miirats". Hadits tersebut memberikan pemahaman bahwa pembunuhan terhadap sang pewaris oleh ahli waris menjadikan halangan baginya untuk mendapatkan warisan, (Az-Zuhaili,: 44).

\section{Klasifikasi Hukum Taklifi.}

Menurut mayoritas ulama hukum taklifi terbagi menjadi lima bagian. Namun, dalam hal penyebutan hukum-hukum tersebut terjadi perbedaan.Kelompok pertama menyebut kelima jenis hukum itu dengan sebutan wujub, tahrim, nadb, karohah dan ibahah.Kelompok kedua menyebutnya dengan sebutan wajib, haram, makruh, mandub dan mubah.

Dalam masalah ini, ternyata kebanyakan orang lebih cenderung menyebut hukum sebagaimana kelompok kedua. Penyebutan tersebut telah amat populer. Padahal, sebagaimana yang dinyatakan oleh Abdul Karim bin Ali dalam karya monumentalnya al-Muhadzab, bahwa yang lebih utama adalah penyebutan dari kelompok pertama. Ia berargumen bahwa wajib bukanlah merupakan sebuah

$\overline{\text { Al-Madãris, Volume 2 (1), } 2021}$ 
hukum, ia hanya sekedar perbuatan seorang mukallaf. Demikian juga mandub, ia adalah perbuatan seseorang yang berkaitan dengan khitab nadb.Berikuturaianhukum taklifi:

a. Wujub, secara bahasa ia mempunyai makna as-Saqith (gugur/roboh), seperti ketika dikatakan wajaba al-Haith yang memiliki arti dinding telah roboh. Sementara secara terminologi, ia diartikan sebagai suatu pekerjaan yang dituntut oleh syari' secara pasti (hatman). Pengambilan makna "pasti" ini bisa diambil dari makna shighot nash secara langsung atau dari qorinah/petuntuk eksternal, (Az-Zuhaili,: 47), namun Abdul karim lebih suka mendefinisikan wujub sebagai sesuatu yang taarik nya (pelanggar) dicela secara syara' dan bersifat mutlak, (Abdul Karim,: 147).

b. Nadb, secara bahasa bermakna ajakan pada suatu pekerjaan. Secara terminologi syara' ia mempunyai arti suatu pekerjaan yang dituntut oleh syari' namun tidak secara pasti. Definisi khususnya adalah suatu pekerjaan yang pelakunya itu dipuji atau dianggap baik dan orang yang meninggalkannya tidak dicela. Pengambilan kesimpulan nadb pada sebuah pekerjaan bisa didapat dari shighat nash yang menunjukkan tuntutan yang tidak secara pasti, seperti shighat yusannu, yundabu dan selainnya.

c. Hurmah, secara bahasa ia bermakna larangan atau pencegahan. Secara istilah ia bermakna sesuatu yang dituntut oleh syari' untuk ditinggalkan secara pasti atau dengan ungkapan lain sesuatu yang pelakunya itu dicela. Pengambilan kesimpulan larangan secara pasti ini bisa diambil dari shighat nash seperti al-hurmah, nafy al-Hill, dan selainnya, (Az-Zuhaili,: 80).

d. Karahah, secara bahasa ia merupakan lawan dari cinta yakni benci, (Abdul Karim,: 283). Sedangkan secara terminologi syara' ia memiliki arti sesuatu yang dituntut oleh syari' untuk ditinggalkan, namun tuntutan larangan ini tidak secara pasti. Pengambilan kesimpulan hukum karahah ini bisa diambil dari shighat nash seperti kurriha atau indikasi lain yang menunjukkan makna karahah. Karahah sendiri terbagi menjadi dua bagian yakni karahah tahrim dan karahah tanzih. Titik perbedaan di antara keduanya adalah terletak pada segi larangan itu berasal. Pada karahah tahrim larangan itu bersifat pasti, namun dihasilkan dari dalil dhonni, seperti larangan meminang wanita yang telah dipinang oleh laki-laki lain. sementara karahah tanzih larangan itu tidak bersifat pasti.

e. Ibahah, secara bahasa ia memiliki arti al-I'lan wa al-Idzhar (menjelaskan). Secara istilah ia memiliki arti sesuatu dimana syari' memberikan pilihan untuk mengerjakan atau meninggalkan suatu pekerjaan, atau dengan kata lain hukum ini tidak terkait dengan konsep pujian maupun cela. Hukum Ibahah ini bisa didapat dari shighat nash al-Hill, al-Ibahah dan lainnya.

Jenis-jenis hukum taklifi di atas adalah jenis-jenis hukum versi mayoritas ulama ushul. Di sisi lain terdapat sebagian ulama yakni mayoritas ulama hanafiyah yang menyatakan bahwa hukum taklifi itu terdapat tujuh jenis yakni fardlu, ijab, karahah tahrim, haram, karahah tanzih, ibahah dan nadb. Menurut mereka perbedaan antara ijab dan fardlu adalah pada ijab tuntutan itu berasal 
dari nash yang dhonni, sementara fardlu berasal dari nash yang qath'i, (Abdul Karim, 1999: 142).

\section{Hakim}

Secara hakikat hakim adalah Allah swt. Semata, tidak ada yang lain. Para utusan Allah hanya sekedar menyampaikan risalah dan hukum-hukumnya saja. Mereka semua tidak menciptakan atau menetapkan hukum. Sementara para mujtahid cuma sekedar menyingkap tabir-tabir hukum. Mereka juga bukan pencipta hukum syariat, sekalipun secara adat mereka juga terkadang disebut hakim, (Abdullah Yusuf al-Juda'i, 1997: 71).

Dalam masalah hakim ini seluruh ulama menyepakati konsep di atas. Terbukti, mereka juga sepakat memaknai hukum sebagai khitabullah bukan khitab ar-Rusul atau khitab al-Mujtahidin. Perbedaan ulama dalam hal ini hanya berkisar tentang hukum Allah yang berkaitan dengan perbuatan orang mukallaf, apakah akal dengan sendirinya mampu mengetahui hukum-hukum tersebut ataukah perlu perantara para rasul untuk dapat mengetahuinya. kelompok.

Terkait perbedaan ini, Abdul wahab khallaf membagi menjadi tiga

d. Mazhab Asy'ariyah, pengikut Abu Hasan al-Asy'ari yang menyatakan bahwa akal dengan sendirinya tidak akan mampu mengetahui hukum-hukum allah tanpa mediasi para rasul dan kitab-kitabnya. Kelompok ini berargumen bahwa yang disebut dengan kebaikan adalah sesuatu yang telah ditunjukkan oleh syari' bahwa hal itu memang baik. Sementara kejelekan adalah sesuatu yang ditunjukkan oleh syari' bahwa hal itu memang jelek. Kebaikan dan keburukan tidak dapat ditentukan oleh penalaran akal semata.

e. Mazhab Mu'tazilah, yakni para pengikut Washil bin Atha' yang menyatakan bahwa dengan sendirinya akal mampu mengetahui hukum-hukum Allah tanpa melalui perantara rasul atau kitab. Mereka berhujjah bahwa sesuatu itu dikatakan baik ketika akal memandang hal itu baik. Sebaliknya sesuatu itu dipandang jelek ketika akal memang menganggap jelek.

f. Mazhab Maturidiyah, pengikut Abu Mansur al-Maturidi, mazhab ini menurut Khallaf adalah mazhab penengah dan dianggap sebagai pendapat yang lebih kuat. Mazhab ini menyatakan bahwa memang akal sehat itu mampu menilai mana yang baik dan mana yang dianggap buruk. Namun, tidak secara otomatis akal mampu menentukan hukum-hukum Allah, sebab kerja akal itu terbatas dan terkadang kerja akal itu berbeda satu sama lain dalam menilai suatu perbuatan. Oleh karena itulah, dalam menentukan hukum-hukum Allah tetap diperlukan adanya perantara utusan dan kitab-kitabnya, (Wahab Khallaf,: 97-99).Pada akhirnya apa yang dipegangi oleh mazhab ini sama dengan pendapat mazhab Asy'ariyah yang tetap menyatakan bahwa untuk mengetahui hukum Allah diperlukan adanya perantara.

Terkait perbedaan para ulama di atas, pendapat yang dipegangi oleh kelompok kedualah yang sebenarnya terasa lebih relevan. Sebab, dalam pendapat kedua ini tersimpan keadilan Tuhan yang begitu luar biasa. Betapa tidak, menurut pendapat ini seorang yang belum sampai dakwah Islam kepadanya,

$\overline{\text { Al-Madãris, Volume 2 (1), } 2021}$ 
akan tetap dituntut sebagai seorang mukallaf berdasar akal yang dianugerahkan padanya. Hal ini logis, sebab salah satu syarat utama seorang mukallaf haruslah ia memiliki akal sehat. Ia dituntut untuk melaksanakan perbuatan yang dianggap baik oleh akal sehatnya dan dituntut meninggalkan perbuatan yang dianggap buruk menurut akal sehatnya pula. Ini merupakan apresiasi yang luar biasa besar terhadap anugerah akal yang diberikan oleh Tuhan.

\section{Mahkum Fih}

Yang dimaksud dengan mahkum fih adalah perbuatan seorang mukallaf yang berkaitan dengan taklif/pembebanan. Taklif yang berasal dari Allah ditujukan pada manusia dalam setiap perbuatan-perbuatannya. Tujuan dari taklif ini tidak lain adalah sebagai bentuk uji coba/ ibtila' dari Allah kepada para hambanya supaya dapat diketahui mana hamba yang benar-benar taat dan mana hamba yang maksiat kepadaNya. Dengan demikian sebuah taklif akan selalu berkaitan erat dengan perbuatan mukallaf dan perbuatan inilah yang disebut dengan mahkum alaih, (M. Sulaiman Abdullah, 2004: 72).

Dari sini terlihat jelas bahwa setiap bentuk taklif adalah perbuatan. Ketika taklif itu berupa taklif ijab atau nadb maka hukum tersebut akan terlaksana dengan adanya sebuah tindakan atau perbuatan dan jika taklif itu berupa karahah atau haram, maka hukum tersebut akan terlaksana pula dengan adanya tindakan/perbuatan meninggalkan. Jadi tindakan pencegahan atau meninggalkan sesuatu itu juga dianggap sebagai sebuah fi'lun (perbuatan).

Terdapat beberapa syarat untuk absahnya sebuah taklif dalam perbuatan, diantaranya adalah:

a. Perbuatan tersebut harus diketahui secara sempurna oleh seorang mukallaf sehingga tergambar tujuan yang jelas dan mampu melaksanakannya. Dengan demikian seorang itu tidak diwajibkan melaksanakan sholat sebelum jelas rukun-rukun dan kaifiyahnya.

b. Perbuatan itu diketahui berasal dari dzat yang mempunyai kewenangan untuk memberikan taklif. Sebab dengan pengetahuan ini seseorang akan mampu mengarahkan kehendak untuk melaksanakannya. Yang perlu diperhatikan dalam masalah ini adalah mengenai pengetahuan. Pengetahuan yang dimaksud adalah imkan al-Ilm (kemungkinan untuk mengetahui) bukan pengetahuan secara praktis. Artinya, ketika seorang itu telah mencapai taraf berakal dan mampu memahami hukum-huum syar'i dengan sendiri atau dengan cara bertanya pada ahlinya, maka ia telah dianggap sebagai orang yang mengetahui apa yang ditaklifkan kepadanya, (Wahab Khallaf,: 129).

c. Perbuatan tersebut harus bersifat mungkin untuk dilaksanakan atau ditinggalkan. Mayoritas ulama menyatakan bahwa taklif itu tidak sah jika berupa perbuatan yang mustahil untuk dikerjakan, seperti mengharuskan untuk melaksanakan dua hal yang saling bertentangan, mewajibkan dan melarang dalam satu waktu, mengharuskan manusia untuk terbang dll. Meski demikian, ternyata masih ada sekelompok ulama yang memperbolehkan taklif pada perbuatan yang mustahil. Pendapat ini dipegangi oleh ulama-ulama dari kalangan Asy'ariyah. Mereka mengajukan hujjah andaikan taklif terhadap hal yang mustahil itu tidak

$\overline{\text { Al-Madãris, Volume 2 (1), } 2021}$ 
diperbolehkan maka tidak akan pernah terjadi, sementara kenyataannya taklif itu telah terjadi, seperti pada kasus taklif yang diberikan pada Abu Jahal untuk beriman dan membenarkan risalah rasul. Dalam hal ini Allah telah mengetahui bahwa Abu jahal tidak akan pernah beriman. Pendapat ini disanggah jumhur bahwa maskipun pada kenyataannya Abu jahal tidak beriman, namun taklif tersebut sebenarnya masih bersifat mungkin dan tidak mustahil bagi abu jahal, (Az-Zuhaili,: 137).

\section{Mahkum Alaih}

Mahkum alaih adalah seorang mukallaf yang perbuatannya itu berkaitan dengan hukum dari syari'.

Perbuatan seorang mukallaf bisa dianggap sebagai sebuah perbuatan hukum yang sah apabila mukallaf tersebut memenuhi dua persyaratan, yaitu:

a. Mukallaf tersebut harus mampu memahami dalil taklif. Artinya, ia mampu memahami nash-nash perundangan yang ada dalam al-Qur'an maupun asSunnah dengan kemampuannya sendiri atau melalui perantara. Hal ini penting, sebab seseorang yang tidak mampu memahami dalil/petunjuk taklif, maka ia tidak mungkin melaksanakan apa yang telah ditaklifkan kepadanya. Kemampuan untuk memahami dalil taklif hanya bisa terealisasi dengan akal dan adanya nash-nash taklif. Akal adalah perangkat untuk memahami dan merupakan penggerak untuk bertindak. Sifat dasar akal ini abstrak, tidak bisa ditemukan oleh indera zhahir, oleh karenanya syari' mengimbangi dengan memberikan beban hukum (taklif) dengan sesuatu yang riil, yang bisa diketahui oleh indera luar yaitu taraf baligh. Pada saat baligh inilah seorang dianggap mampu untuk memahami petunjuk-petunjuk taklif. Praktis, orang gila dan anak kecil tidak tercakup dalam kategori mukallaf, (Wahab Khallaf,: 134).

b. Seorang itu diharuskan Ahlan lima kullifa bihi /cakap atas perbuatan yang ditaklifkan kepadanya. Secara bahasa ahlan bermakna Shalahiyah/ kecakapan. Sementara kecakapan itu sendiri akan bisa terwujud dengan akal. Terkait dengan hal ini, Al-Amidi, sebagaimana dikutip oleh azZuhaili mengatakan bahwa para cendikiawan Muslim sepakat bahwa syarat untuk bisa disebut sebagai seorang mukallaf adalah berakal dan paham terhadap apa yang ditaklifkan, sebab taklif adalah khitab dan khitabnya orang yang tidak berakal adalah mustahil, layaknya batu padat dan hewan. Ulama ushul membagi jenis kecakapan ini menjadi dua bagian yaitu:

1) Ahliyah al-Wujub, yaitu kecakapan manusia untuk menerima hak dan kewajiban, (Az-Zuhaili,: 163), Pijakan utama dari konsep ahliyah alWujub ini adalah adanya kehidupan, artinya selama orang itu bernafas maka orang tersebut bisa disebut sebagai ahliyah al-Wujub. Ahliyah ini terbagi menjadi dua, yaitu ahliyah al-Wujub Naqishah dan Ahliyah alWujub Kamilah. Jenis ahliyah yang pertama adalah jika seorang itu cakap untuk menerima hak saja bukan kewajiban, seperti janin yang masih berada dalam kandungan ibunya. Ia masih bisa menerima hak untuk mewarisi, tetapi ia tidak bisa menerima kewajiban yang dibebankan kepadanya. Sedangkan yang kedua adalah ketika seorang 
itu mampu menerima hak sekaligus kewajibannya. Ini berlaku kepada setiap manusia.

2) Ahliyah al-Ada', yaitu kecakapan seseorang untuk bertindak. Artinya, tindakan orang tersebut baik berupa perbuatan maupun ucapan, secara syariat telah dianggap "absah" (mu'tabaran syar'an). Terkait dengan konsep ini, manusia terbagi menjadi tiga jenis klasifikasi, yaitu: Pertama, Seseorang tidak mempunyai kecakapan bertindak sama sekali seperti orang gila dan anak kecil. Kedua, seorang tersebut mempunyai kecakapan bertindak namun belum sempurna, seperti anak mumayyiz yang belum sampai pada taraf baligh dan orang idiot (ma'tuh).Ketiga, Seseorang yang mempunyai kecakapan bertindak secara sempurna seperti seworang yang telah berakal dan baligh.

\section{F. Kesimpulan}

Dalam istilah ulama ushul, hukum didefinisikan sebagai suatu khitab syari' yang berkaitan dengan perbuatan-perbuatan mukallaf, baik yang bersifat thalab (tuntutan), takhyiir (pilihan) atau wadli (ketetapan). Sedangkan hukum menurut pakar fiqih adalah suatu sifat syar'i yang merupakan pengaruh dari khitab tersebut. Dengan demikian, pengaruh khitab Allah yang berimplikasi pada kewajiban mendirikan shalat dari ayat "Aqiimu as-Sholaah" adalah sebuah hukum. Secara hakikat hakim adalah Allah swt. Semata, tidak ada yang lain. Para utusan Allah hanya sekedar menyampaikan risalah dan hukum-hukumnya saja. Mereka semua tidak menciptakan atau menetapkan hukum. Sementara para mujtahid cuma sekedar menyingkap tabir-tabir hukum. Mereka juga bukan pencipta hukum syariat, sekalipun secara adat mereka juga terkadang disebut hakim. Mahkum fih adalah perbuatan seorang mukallaf yang berkaitan dengan taklif/pembebanan. Taklif yang berasal dari Allah ditujukan pada manusia dalam setiap perbuatan-perbuatannya.Mahkum alaih adalah seorang mukallaf yang perbuatannya itu berkaitan dengan hukum dari syari'.

\section{BIBLIOGRAFI}

Abdullah, Muhammad Sulaiman. (2004). al-Wadhih fi Ushul al-Fiqh. Damaskus: Dar as-Salam.

Ali, Abdul Karim. (1999). Al-Muhadzab fi 'Ilm Ushul al-Fiqh al-Muqaran. Riyadh: Maktabah ar-Rusyd.

Al-Judai', Abdullah bin Yusuf. (1997). Taysiir 'Ilm Ushul al-Fiqh. Beirut: Muassasah ar-Rayyan.

Prastowo, Andi. (2011). Metode Penelitian Kualitatif dalam Perspektif Rancangan Penelitian. Yogyakarta: Ar Ruzz Media.

Az-Zuhaili, Wahbah. (1999). Al-Wajiizfi Ushul al-Fiqh. Beirut: Daar al-Fikr.

Az-Zuhaili, Wahbah. (n.d). Ushul Fiqh al-Islami. Beirut: Daar al-Fikr.

Nawawi, Hadari. (1993). Metode Penelitian Bidang Sosial. Yogyakarta: Gajah Mada University Press.

Khallaf, Abdul Wahab. (1978). 'Ilm Ushul al-Fiqh. Cairo: Daar al-Qalam.

Rifa'i, Muhammad. (1999). Usul Fiqh. Bandung: al-Ma'arif.

$\overline{\text { Al-Madãris, Volume 2 (1), } 2021}$ 
Sugiono. (2011). Metode Penelitian Kualitatif, Kuantitatif dan Re D. Bandung: Alfabeta. Hadi, Sutrisno. (1990). Metodologi Research. Yogyakarta: Andi Offset. 